\title{
Feasibility Based on Production Patterns by Home Industries in Hargotirto, Kokap, Kulon Progo, Yogyakarta
}

\author{
Triwara Buddhi Satyarini ${ }^{1, *}$, Sutrisno ${ }^{2}$, Fitri Wira Kartika ${ }^{3}$ \\ 1,2,3 Department of Agribusiness, UniversitasMuhammadiyah Yogyakarta, Indonesia
}

\begin{abstract}
This study aims to determine the pattern of coconut sugar production and compare the income and business feasibility of each production pattern. Utilizing proportionate stratified random sampling, 90 respondents of industrialists were gathered. There are three production patterns coconut sugar home industry: pattern (1) processing the formed coconut sugar (60 home industry), pattern (2) processing the brown sugar (21 home industry), and pattern (3) processing formed coconut sugar into brown sugar (9 home industry). The average income of pattern (1) IDR 695,010 per month, pattern (2) IDR 787,745 per month, and pattern (3) IDR 2,326,578 per month. The values of business feasibility based on R/C were: pattern (1) 1.001; pattern (2) 1.057 and pattern (3) 1.056. Business feasibility based on capital productivity obtained pattern (1) $187.7 \%$, pattern (2) $152.4 \%$, and pattern (3) $6.2 \%$. Business feasibility based on labor productivity per (man days) was: pattern (1) IDR 65,569, pattern (2) 67,820 IDR, and pattern (3) 290,289 IDR. The results of study revealed that the most preferred production pattern was pattern (1) processing to formed coconut sugar. The three production patterns were feasible $(\mathrm{R} / \mathrm{C}>1)$. Pattern (3), processing formed coconut sugar into the brown sugar, was the most productive.
\end{abstract}

\section{Introduction}

Coconut sugar is a processed product derived from coconut juice (sap), obtained by evaporating coconut juice (Cocos nucifera L.) until reaching its saturated liquid and formed a crystalline structure. and then formed [1, 19]. Coconut juice is a liquid produced from coconut flower bunches. Coconut sugar is widely used as a sweetener and gives a brown color to food and is widely consumed by the community to provide a sweet and healthy taste [2]. Compared to white sugar, formed coconut sugar and brown sugar have higher protein levels, fat, calcium, phosphorus, and iron [3]. Coconut Sugar May Have a Lower Glycemic Index whereas coconut sugar around of 54 [16]. Coconut sugar is becoming popular as an alternative to beetroot or cane sugar due to its high mineral content and lower glycaemic index. As its market price is about twice as high as that of conventional sugar, coconut sugar may become target to fraudulent manipulation.(24) The amount of coconut sugar consumption continues to increase in line with the increasing population. This increase in consumption results in an increase in business opportunities for coconut sugar 
production. According the result of [15], developing market penetration strategies and product development strategy is an alternative strategy to developed and applied in the development of coconut sugar business group Bonedaa Village, Bone Bolango District One of the coconut sugar production centers in Java is in Kokap District, Kulon Progo Regency, Special Region of Yogyakarta. Table 1 illustrates the distribution of coconut production in Kulon Progo Regency based on the district.

Table 1.Plantation Area and Coconut Plant Production in Kulon Progo Regency, 2017

\begin{tabular}{|l|r|r|r|}
\hline District & Plant area (Ha) & Yielding crops (Ha) & Production (tons) \\
\hline Temon & 1393.33 & 1317.31 & 2.27 \\
\hline Wates & 1310.64 & 1132.00 & 2.46 \\
\hline Panjatan & 1964.48 & 1480.09 & 4.38 \\
\hline Galur & 2358.52 & 2124.00 & 4.18 \\
\hline Lendah & 1658.82 & 1452.45 & 2.58 \\
\hline Sentolo & 1137.92 & 1025.54 & 2.34 \\
\hline Pengasih & 1682.00 & 1606.50 & 2.83 \\
\hline Kokap & 2998.50 & 2881.00 & 4.72 \\
\hline Girimulyo & 950.71 & 887.50 & 1.64 \\
\hline Nanggulan & 1051.19 & 838.00 & 1.46 \\
\hline Kalibawang & 796.68 & 737.34 & 1.44 \\
\hline Samigaluh & 949.00 & 874.00 & 1.42 \\
\hline
\end{tabular}

Source: [17]

Coconut sugar production in Kulon Progo Regency is an agricultural, cultural heritage passed down from generation to generation. The majority of production is carried out traditionally with simple technology on a micro-scale (home industry) with family labor. A large number of producers have made the formed coconut sugar and brown sugar agroindustries their preferred livelihoods to fulfill their daily needs and is generally carried out by both men and women in one household [4]. Coconut sugar or palm sugar is superior product in Banyumas regency, which supported by widespread of coconut tapping trees covering 5,157 ha and production of coconut sugar reach 57,400 tons per year, but welfare of coconut sugar entrepreneur are still relatively low [21]. Data as of March 22, 2015 in US So how did coconut palm sugar grow $100.4 \%$ in one year [22]. The activities of tapper palm farmers in South Halmahera district can, contributing to increase the socio-economic welfare of farmers tapping palm [23]

Initially, the pattern of coconut sugar production was to process sap into formed or blocked coconut sugar, referred to as pattern 1. The formed coconut sugar is processed from heated sap, thereby evaporating and leaving a solid brown and sweet sediment. When it is still hot, the sediment is then formed to be a tube block or semicircle [1]. Then the coconut sugar production pattern develops, processing the sap into crystal sugar or brown sugar, termed as pattern 2. Finally, the production pattern of brown sugar from formed/block coconut sugar has begun, defined as pattern 3 . The novelty of this research is to compare the three production patterns to determine which one is the most feasible and productive

This research raises a question on which pattern is the most profitable and feasible to be developed. This study compares the business feasibility of three coconut sugar production patterns developed in Kulon Progo, Yogyakarta Special Region. Although coconut sugar production is growing in number [5], the majority of coconut sugar producers are living in poverty. This research is expected to be the basis for the most profitable and feasible production options to develop. 


\section{Research Methods}

The research location was determined purposively in Kokap District for being the highest planting area [17] and amount of production. Hargotirto Village was chosen for possessing the largest number of producers (home industry), as presentedin the following table.

Table 2. Number of Producers (Home Industry) of Coconut Sugar in Kokap District

\begin{tabular}{|l|r|}
\hline Village Name & Number of Producers (Home Industry) \\
\hline Hargorejo & 188 \\
\hline Hargotirto & $\mathbf{9 7 6}$ \\
\hline Hargowilis & 86 \\
\hline Jatimulyo & 344 \\
\hline Kalirejo & 18 \\
\hline Total & $\mathbf{1 5 8 0}$ \\
\hline
\end{tabular}

Source: [18]

The number of research respondents was determined by the Slovin formula, namely 90 out of 976 producers. A sampling of respondents was carried out using proportional stratified random sampling, based on the average production amount per year. Randomly selected 32 out of 343 producers in the high production category, 47 out of 513 producers in the medium production category, and 11 out of 120 producers in the low production category.

The research was conducted in a survey with interview techniques with a questionnaire guide. Primary data obtained from producers were the number of inputs in the production process, input prices, production quantities, product prices, number of labor, labor wages, and other costs. This study employed an analysis of costs, income, and profits. Business feasibility was calculated using the Revenue Cost Ratio (R/C) analysis, labor productivity, and capital productivity [6]. The research was carried outduring the production period of March $1-31,2019$. The prices used were the prices in effect at the time of the research. The assumption utilized was that producers were rational (profit orientation), and all production was sold, or the production value was calculated. The data were presented descriptively in the form of tables. The comparison of business feasibility was carried out using table analysis.

\section{Results and Discussion}

\subsection{Profile of Respondents}

The respondents of this study were 90 producers (home industry). The number of respondents identified as pattern 1 was 60 people, pattern 2 was 21 people, and pattern 3 was 9 . The distribution of producers revealed that pattern 1, producing formed sugar from sap, was the most preferred. Pattern 1 wasthe first pattern recognized by the community, and many have been passed down from generation to generation. Pattern 2 is processing sap into brown sugar with 21 producers. It is a production pattern known after pattern 1. Pattern 2 has been known since the 1990s, an innovation brought by community empowerment activists from various campuses and NGOs. Technology develops due to market opportunities connected by community empowerment facilitators. Until now, this market opportunity is still available.

Meanwhile, pattern 3, processing formed sugar into brown sugar, was started by the activist of the Multi-Purpose Cooperative (KSU) Jati Rogo, who developed export 
marketing in the form of ant sugar, since sugar producers have not been able to meet the demand for the export market. The KSU managers, driven by 9 people, ended up producing brown sugar. However, the material was not made from sap, but coconut sugar was formed in block. The formed coconut sugar wasthen processed with more advanced technology to become brown sugar and was marketed overseas.

Tabel 3. Profile of Respondents by Production Pattern

\begin{tabular}{|c|c|c|c|c|}
\hline No & Profile & $\begin{array}{c}\text { Pattern 1 } \\
60 \text { home industry }\end{array}$ & $\begin{array}{c}\text { Pattern } 2 \\
21 \text { home industry }\end{array}$ & $\begin{array}{c}\text { Pattern } 3 \\
9 \text { home industry }\end{array}$ \\
\hline \multicolumn{5}{|c|}{ A. Gender } \\
\hline 1. & Male & 48 & 13 & 8 \\
\hline 2. & Female & 12 & 8 & 1 \\
\hline \multicolumn{5}{|c|}{ B. Education } \\
\hline 1. & Elementary School & 38 & 14 & 4 \\
\hline 2. & Junior High School & 11 & 4 & 0 \\
\hline 3. & Senior High School & 8 & 1 & 4 \\
\hline 4. & University & 2 & 1 & 1 \\
\hline 5. & No school & 1 & 1 & 0 \\
\hline \multicolumn{5}{|c|}{ C. Business Experience (years) } \\
\hline & $3-10$ & 6 & 5 & 5 \\
\hline & $11-20$ & 7 & 5 & 1 \\
\hline & $21-30$ & 22 & 7 & 2 \\
\hline & $\geq 31$ & 25 & 4 & 1 \\
\hline
\end{tabular}

According to the profile in table 3, the producers in the coconut sugar home industry were still dominated by men. The education level of producers wasrelatively evenly distributed, the majority of which wereelementary school graduates. In pattern 3 , the percentage of high school education wasindeed higher. Interestingly, pattern 3 was dominated by new producers who have begun their business in less than 10 years. They were young people relatively progressive and had broader business insights, than those of pattern 1 or pattern 2, dominated by producers who have been in business for more than 30 years. more than 30 years of working still on a home industry scale. Maybe it needs a touch of policy from the government to make it more developed, such as research results about Pacitan District Government Policy Implementation in the Sugar Coconut Industry, the Micro Cooperative and Business Office and the Pacitan Regency Industry and Trade Office in order to increase coconut sugar SMIs carry out coaching and facilitation. The guidance and facilitation includes training, work equipment facilities, product legality facilities, promotional facilities and capital facilities [25].

\subsection{Production Cost Analysis}

Table 4 depicts that either pattern 1 or 2 required affordable production costs. The amount of this cost waswhat people considered in choosing the production pattern in their business. The real (explicit) costs incurred less than IDR 500,000 per month. The majority of them did not pay attention to implicit costs not incurred. While pattern 3 was chosen by a few producers due to the larger scale of the business, using a lot of tools and materials, thereby requiring large total costs. Accordingly, only a few producers were interested in developing pattern 3 as the costs were more than IDR 30,000,000 per month. 
Table 4. Results of Cost Analysis for Each Production Pattern Per Month (IDR)

\begin{tabular}{|c|c|c|c|c|}
\hline No & Type of Costs & Pattern 1 & Pattern 2 & Pattern 3 \\
\hline A. & Explicit Costs & & & \\
\hline 1. & Production inputs & 282,863 & 407,952 & $33,048,333$ \\
\hline 2. & Depreciation cost & 16,710 & 22,150 & 33,422 \\
\hline \multirow[t]{2}{*}{3} & Labor fees & 0 & 0 & $1,838,333$ \\
\hline & Total A & 299,573 & 430,103 & $34,920,088$ \\
\hline $\mathbf{B}$ & Implicit Costs & & & \\
\hline 1. & Production inputs & 559,824 & 587,659 & 0 \\
\hline 2. & Family Labor fees & 66,108 & 65,495 & 90,000 \\
\hline 3. & Rent room & 66,667 & 66,667 & 66,667 \\
\hline \multirow[t]{3}{*}{4.} & Own capital interest & 1,748 & 2,509 & 203,701 \\
\hline & Total B & 694,347 & 722,330 & 360,367 \\
\hline & Total Costs $(\mathrm{A}+\mathrm{B})$ & 993,920 & $1,152,432$ & $35,280,455$ \\
\hline
\end{tabular}

\subsection{Income and Profit Analysis}

Table 5 illustrates that the average production amount of producers in pattern 1 and pattern 2 was only around $60 \mathrm{~kg}$. If in one month the production was carried out four times (once a week), then the production for a week wasaround $15 \mathrm{~kg}$. This number was still relatively low. On average, producers in patterns 1 and 2 still relied on the raw material for the sap from their trees. The revenue received by coconut sugar was 695,010 IDR, with average production for one month of $61.8 \mathrm{~kg}$.It was smaller than the revenue obtained in the coconut brown sugar business in Medono Village, Kaliwo District, Wonosobo Regency, namely IDR 803,763.50 with $80.59 \mathrm{~kg}$ sugar production for one month [7].

Very striking in pattern 3, producers could produce 1.8 tons of brown sugar per month, indicating a large business scale and the ability to absorb large raw materials. Pattern 3 was carried out by producers with comprehensive market insights. They also obtained higher prices for entering the export market. In a nutshell, processing brown sugar was more profitable but on a large scale and with a range of markets outside the region or exports. If the producers of printed coconut sugar (pattern 1) want to continue producing printed sugar, they must enlarge their business scale. Raw materials do not only rely on their coconut trees. According the result of the research if traditional coconut sugar proccesed was the least hygroscopic $(1.21 \times 10-4 \mathrm{~g}$ water/g solid/minutes) [20].

If pattern 2 is to be developed, the business pattern must be improved with raw materials buying sap from other people or shift toward pattern 3, utilizing printed coconut sugar as raw material. Pattern 2 could also be encouraged to enter foreign markets or export markets to obtain a higher selling price.

Whereas for capital owners, pattern 3 was the appropriate alternative to begin a coconut sugar business, as long as it could build markets outside the region or export markets.

Table 5.Analysis Results of Producer Income and Profits Per Month (IDR)

\begin{tabular}{|c|c|c|c|c|}
\hline No & Description & Pattern 1 & Pattern 2 & Pattern 3 \\
\hline A. & Income & & & \\
\hline 1. & Total Production $(\mathrm{kg})$ & 61.8 & 65.5 & 1.868 \\
\hline 2. & $\begin{array}{l}\text { Production Price (IDR) } \\
\text { (IDR }\end{array}$ & 16,150 & 18,690 & 20,111 \\
\hline 3. & Revenue (IDR) & 994,583 & $1,217,848$ & $37,246,667$ \\
\hline & Total Income & 695,010 & $\mathbf{7 8 7 , 7 4 5}$ & $2,326,578$ \\
\hline B & The Advantage & 664 & 65,415 & $1,966,211$ \\
\hline
\end{tabular}




\subsection{Business Feasibility Analysis}

Table 6 exhibits that the $\mathrm{R} / \mathrm{C}$ of each pattern was merely around 1. Even though it is greater than 1 , this business is hazardous because the ratio of costs incurred to benefits is almost the same. From the aspect of BCR analysis, this effort is worth the effort but needs to be careful. The results of this study are in line with the research of Azhar et,al [8], reveale that the coconut sugar home industry in Pastap Julu Village was feasible to be developed because the $\mathrm{R} / \mathrm{C}$ value was 2.84 (more than 1 ).

However, the research conducted on the coconut sugar producer in Tasikmalaya Regency had an average income of IDR 590,200 per production with an $\mathrm{R} / \mathrm{C}$ value of greater than 1.5 , which was 1.92 ; therefore, the brown sugar business was feasible to run because the R/C value was greater than 1 [9]. Similar results were also obtained by research with the same effort in Karangreji Village, Garum District, Blitar, namely an R/C value of 1.2 with an income of IDR 3,357,789.47 per month [10]. The results of research on the feasibility of the home industry for other products in the same area, namely DIY can be used as a comparison with the feasibility of the coconut sugar home industry, for example the results of research by B.S Sinaga [11] on the tofu home industry in Sleman obtained an $\mathrm{R} / \mathrm{C}$ value of 1.22. Moreover, research by Nugroho [12] discovered an $\mathrm{R} / \mathrm{C}$ value of1.38 in the tofu industry in Bantul Regency.

Regarding labor productivity, conventional production patterns (patterns 1 and 2) wereless attractive sincethe wages per man-dayswerestill around IDR 65.000. The reality in the field disclosed that the younger generation was not interested in developing a coconut sugar business. Apart from the low wages, they have to wait for the product to be marketed at least a week before receiving the money from sales. They preferred to work in other sectors, such as construction, factory, or others. Pattern 3 implied development prospects both in terms of feasibility based on labor productivity and capital productivity.

The brown sugar industry made from coconut sugar can be developed, but it requires capital support, foreign markets, or exports as well as the support of coconut sugar raw materials. One thing that can be developed is business partnership pattern 3 with pattern 1 . This partnership will guarantee the stability of raw materials and prices.

Table 6. Results of Business Feasibility Analysis

\begin{tabular}{|c|l|c|c|c|}
\hline No & Description & Pattern 1 & Pattern 2 & Pattern 3 \\
\hline 1. & R/C & 1.001 & 1.057 & 1.056 \\
\hline 2. & $\begin{array}{l}\text { Labor Productivity (IDR } \\
\text { perman-days) }\end{array}$ & 65,569 & 67,820 & 290,289 \\
\hline 3. & Capital Productivity (\%) & 187.7 & 152.4 & 6.2 \\
\hline
\end{tabular}

The description of a home industry development with more modern management and market expansion can increase business feasibility from labor productivity. Of the three patterns, the $\mathrm{R} / \mathrm{C}$ value is almost the same, but for the productivity of the most productive labor is pattern 3, this is because in this pattern the raw material that is processed is in the form of printed sugar, while patterns 1 and 2 are sap. This affects the processing time from raw materials to final products because the processing stage takes a long time to reduce the moisture content of the sap so that it thickens and can be printed or processed further into brown sugar. For pattern 3, it only continues processing printed sugar into brown sugar so that at the same time it can process more raw materials into the final product, namely brown sugar. However the household industry of granular brown sugar in Kulon Progo made of formed coconut sugar based on $\mathrm{R} / \mathrm{C}$ show that the industry is not feasible to develop, but shows that the value added of IDR 1.427and that made of coconut sap is IDR 793. While, the valueadded of brown sugar in Purworejo is IDR 644. [13] The coconut sugar home 
industry, compared to other home industries, has a lower feasibility level measured from capital productivity, $\mathrm{R} / \mathrm{C}$ and labor productivity for the same area, namely DIY.The development of the Nata De Coco home industry in Bantul [13], uncovered labor productivity of IDR 173,039 perman-days and capital productivity of $216.22 \%$ per month. Zahran's research [14] on vaname shrimp pond farming in Temon, Kulon Progo Regency, discovered the feasibility of the $\mathrm{R} / \mathrm{C}$ aspect of 1.83 as the marketing opportunity was still wide open. The nutmeg syrup home industry in Ngade Village, Ternate City will gain the Net B/C Ratio analysis resulted 1,427531083> 1 [20].

\section{Conclusions}

- Three production patterns of coconut sugar in Kokap, Kulon Progo comprised processing the sap into formed coconut sugar (pattern 1), processing the sap into brown sugar (pattern 2), and processing the formed coconut sugar into brown sugar (pattern 3).

- The value of business feasibility based on the R/C analysis wasrelatively the same. Nevertheless, the productivity analysis of capital and labor inpattern 3 was mostly different.

- If the community sticks to pattern 1 or 2 , it is highly suggested to develop the scale of the business by enlarging the raw materials that do not only rely on sap from their coconut trees.

- The development of pattern 3 requires technological support, export markets, or outside the region and a partnership of coconut sugar raw materials with producers in pattern 1 .

\section{References}

1. F. Pratama, W.H. Susanto, I. Purwantiningrum, Making printed coconut sugar from naturally fermented sap (Study of the Effect of Anti-Inversion Concentration and Sodium Metabisulfite), JFA, 34 (2014)

2. C. Zuliana, E. Widyastuti, W.H. Susanto, Making Coconut Ants Sugar (Study of Coconut Sugar Ph and Sodium Bicarbonate Concentration), JFA, 41 (2015)

3. I. Irmawati, H. Syam, Financial Feasibility Analysis and Development Strategy for Palm Sugar Home Industry Businesses from Nira Nipah Nira in Pallantikang Village. JATE, 11, 76-94 (2018)

4. A. Martono, S. Budiningsih, W. Watemin, Analysis of Economic Feasibility of the Agroindustry of Printed Coconut Sugar in Jalatunda Village, Mandiraja District. Agritech,91 (2007)

5. D.D. Tarigans, Diversification of Coconut Farming as an Effort to Increase Farmers' Income, Perspektif,42 (2015)

6. Soekartawi, Farming Analysis, University of Indonesia-Press, (1995)

7. M. Mugiono, S.Marwanti, S.N. Awami, Coconut Sugar Business Revenue Analysis (Case Study in Medono Village, Kaliwiro District, Wonosobo Regency), MEDIAGRO, 102 (2014)

8. Azhar, I., Riswan, Risnasari, I., Aulin, F. R., \& Muhdi. (2020). Feasibility analysis of sugar palm (Arenga pinnata Merr) by the people around Batang Gadis National Park area. In IOP Conference Series: Earth and Environmental Science (Vol. 454). 
9. C. Pardani, Increased income of sugar craftsmen through the ant sugar agroindustry in Tasikmalaya Regency. Mimbar Agribusiness11, 23-30 (2017)

10. D.B. Prasetiyo, A.W. Muhaimin, S. Maulidah, Analysis of Added Value of Coconut Nira in Coconut Brown Sugar Agroindustry (Case In Red Sugar Agroindustry of Karangrejo Village, Garum District, Blitar).JAEA 21, 41-51 (2018)

11. B.S. Sinaga,Feasibility Analysis of Tofu Industry in Banyuraden Village, Gamping District, Sleman Regency,Undergraduate Thesis, (2018)

12. A. Nugroho, Feasibility of Tofu Home Industry in Karanganyar Village, Weru District, Sukoharjo Regency, Undergraduate Thesis,(2017)

13. Prihtanto, F. N. P., Irham, I., \& Suryantini, A. (2017). Industry Analysis Of Household Brown Sugar For Exporting In Kulon Progo And Purworejo District. Agro Economics, 26 (1), 22

14. Zahran, Nisrina Lutfi, A Comparative Study of the Feasibility of a Vaname Shrimp Farming Business with Intensive and Traditional Cultivation in Jangkaran Village, Temon Kulon Progo,(2018)

15. Umar, Z. (2016). The Development Strategy of Coconut Sugar Industry. The International Journal of Engineering and Science, 5(3), 58-66.

16. Gunnar, K(2018). Coconut Sugar - A Healthy Sugar Alternative or a Big, Fat Lie? Journal : Healthline,(2018) 1-12

17. Kulon Progo Regency in Figures 2017. (BPS Yogyakarta)

18. Multi-Purpose Cooperative (KSU) Jati Rogo(2019)

19. Bambang N, Nandi Wahyu K S, Annisa P,Widanti, Resi R, Ziske Ni, Bayu R \& Marleen H (2018). Comparison of crystallized coconut sugar produced by traditional method and amorphous coconut sugar formed by two drying methods: vacuum drying and spray drying, International Journal of Food Properties, 21:1

20. Nurhadi, Bambang Sukri, Nandi Sugandi, Wahyu Kristian Widanti, Annisa Puteri Restiani, Resi Noflianrini, Ziske Rezaharsamto, Bayu Herudiyanto, Marleen (2018). Comparison of crystallized coconut sugar produced by traditional method and amorphous coconut sugar formed by two drying methods: Vacuum drying and spray drying. International Journal of Food Properties (2018) 21(1) 2339-2354

21. Suliyanto1, Agus Suroso1, Dian Purnomo Jati1(2013). Potential and Problems of Small Medium Enterprise (SMEs) Coconut-Sugar: Case Study in Banyumas Regency, Central Java Indonesia.International Journal of Business and Management; Vol. 8, No. 3; 2013

22. Crane, M.(2015)Coconut Sugar is the Fastest Growing Natural Sweetener in the U.S. Nutritional Outlook 2015

23. Usman, A., Suman, A., Hakim, L., \& Muhaimin, W. (2014). The Impact of HomeBased Business Processing Palm Sugar to Increase Socio-Economic Welfare of Farmers In South Halmahera Regency. IOSR Journal of Business and Management, 16(11), 32-37. https://doi.org/10.9790/487x-161153237

24. Tereza Zdiniakova1, María Beatriz de la Calle1(2020) Feasibility study about the use of element profles determined by ED-XRF as screening method to authenticate coconut sugar commercially available. European Food Research and Technology (2020) 246:2101-2109.https://doi.org/10.1007/s00217-020-03559-z. Received: 5 February 2020 / Revised: 25 June 2020 / Accepted: 28 June 2020 / Published online: 13 July 2020 
25. Ganis Sukoharsono E, Setyowati E.(2019). Pacitan District Government Policy Implementation in the Sugar Coconut Industry Promotion and Development on Fta. The International Journal of Accounting and Business Society (2019) 27(3) 